\title{
From Cottesloe (1961) to Trondheim (2016): The journey of the Dutch Reformed Church back into the ecumenical family of the World Council of Churches
}

\begin{tabular}{|c|c|}
\hline $\begin{array}{l}\text { Author: } \\
\text { Daniel Buda }{ }^{1,2,}\end{array}$ & \\
\hline $\begin{array}{l}\text { Affiliations: } \\
{ }^{1} \text { Lucian Blaga } \\
\text { Sibiu, Romania }\end{array}$ & University, \\
\hline $\begin{array}{l}{ }^{2} \text { Department } \\
\text { History and Ch } \\
\text { Faculty of The } \\
\text { Religion, Unive } \\
\text { Pretoria, Soutr }\end{array}$ & $\begin{array}{l}\text { f Church } \\
\text { urch Polity, } \\
\text { ology and } \\
\text { ersity of } \\
\text { Africa }\end{array}$ \\
\hline $\begin{array}{l}{ }^{3} \text { World Counci } \\
\text { Geneva, Switz }\end{array}$ & $\begin{array}{l}\text { I of Churches, } \\
\text { erland }\end{array}$ \\
\hline $\begin{array}{l}\text { Research Proje } \\
\text { Project Leader } \\
\text { Project Numb }\end{array}$ & $\begin{array}{l}\text { ct Registration: } \\
\text { r: J. Pillay @ } \\
\text { er: } 04653484\end{array}$ \\
\hline $\begin{array}{l}\text { Description: } \\
\text { Reverend Dr B } \\
\text { participating ir } \\
\text { 'African Christi } \\
\text { Development', } \\
\text { Prof. Dr Jerry P } \\
\text { the Faculty of } \\
\text { Religion, Unive } \\
\text { Pretoria. }\end{array}$ & $\begin{array}{l}\text { uda is } \\
\text { the project, } \\
\text { lanity and } \\
\text { directed by } \\
\text { illay, Dean of } \\
\text { Theology and } \\
\text { ersity of }\end{array}$ \\
\hline $\begin{array}{l}\text { Correspondin } \\
\text { Daniel Buda, } \\
\text { daniel.buda@ }\end{array}$ & $\begin{array}{l}\text { g author: } \\
\text { wcc-coe.org }\end{array}$ \\
\hline $\begin{array}{l}\text { Dates: } \\
\text { Received: } 26 \mathrm{~J} \\
\text { Accepted: } 10 \mathrm{~A} \\
\text { Published: } 24\end{array}$ & $\begin{array}{l}\text { une } 2018 \\
\text { Aug. } 2018 \\
\text { Oct. } 2018\end{array}$ \\
\hline $\begin{array}{l}\text { How to cite th } \\
\text { Buda, D., } 2018 \\
\text { Cottesloe (196 } \\
\text { Trondheim (20 } \\
\text { journey of the } \\
\text { Reformed Chu } \\
\text { the ecumenica } \\
\text { World Council } \\
\text { HTS Teologiese } \\
\text { Theological St } \\
\text { a5170. https:/ } \\
\text { 10.4102/hts.v }\end{array}$ & $\begin{array}{l}\text { is article: } \\
\text {, 'From } \\
1 \text { ) to } \\
\text { 16): The } \\
\text { Dutch } \\
\text { rch back into } \\
\text { I family of the } \\
\text { of Churches', } \\
\text { Studies/ } \\
\text { udies } 74(4) \text {, } \\
\text { /doi.org/ } \\
74 \text { i4.5170 }\end{array}$ \\
\hline Read online: & \\
\hline 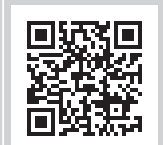 & $\begin{array}{l}\text { Scan this QR } \\
\text { code with your } \\
\text { smart phone or } \\
\text { mobile device } \\
\text { to read online. }\end{array}$ \\
\hline
\end{tabular}

\begin{abstract}
This article presents an analysis of the journey of the Dutch Reformed Church (South Africa) back into the ecumenical fellowship of the World Council of Churches (WCC). The first part contains a brief historical review of the relationships between the WCC and the Dutch Reformed Church family, underlining the fact that the Dutch Reformed Church family in South Africa is a founding member of WCC and that it was never excluded from WCC fellowship; rather, this church itself resigned membership in the WCC after the Cottesloe Consultation (1961) at the pressure of the South African government of that time. The last part presents in detail the process of the readmission of the Dutch Reformed Church into the WCC fellowship (2012-2016) as well as the way this church was active in the WCC after readmission (2016-2018).
\end{abstract}

\section{Introduction}

This article tells the story of the journey of the Dutch Reformed Church (South Africa) back into the ecumenical family of the World Council of Churches (WCC). ${ }^{1}$ One of the reasons I have chosen to write about this matter (readmission of the Dutch Reformed Church to the WCC fellowship) is the fact that as a WCC employee, I have dealt with applications of churches for membership in the WCC since 2008, so I was professionally and, as the process developed, also personally involved in this journey. There is a paucity of literature about this process; therefore, this article was written based more on correspondence (emails or official letters) between the leadership of the Dutch Reformed Church and the WCC, on reports of WCC staff members and team visits presented to WCC governing bodies and on press releases and declarations than on classical sources used by scholars, like books, articles or studies. The purpose of this article is simply to tell the story of this special journey in a systematic way and to offer a preliminary analysis of this unique achievement both in the life of the Dutch Reformed Church and in the history of the WCC.

\section{A brief historical review of the relationship between the World Council of Churches and the Dutch Reformed Church}

Although the title of this article is 'From Cottesloe to Trondheim', and therefore it is supposed to cover the period between 1961 and 2016, I would like to make some references to the previous history of relationships between the WCC and the Dutch Reformed Church. The very first idea that necessarily needs to be underlined here is that the Dutch Reformed Church family from what would later become South Africa was involved in the ecumenical process that led to the creation of the WCC in the first part of the 20th century. For example, I found in the WCC archives a letter, dated 29 September 1936, addressed to the Dutch Reformed Church of Cape and Stellenbosch to attend the World Conference on 'Church, Community and State', which was planned to take place on 12 July 1937 - 25 July 1937, under the auspices of the Universal Christian Council for Life and Work (WCC Archives: 1937).

The Dutch Reformed Church was present also in the Amsterdam Assembly, from 22 August 1948 to 04 September 1948 when the WCC was founded. Therefore, the Dutch Reformed Church family

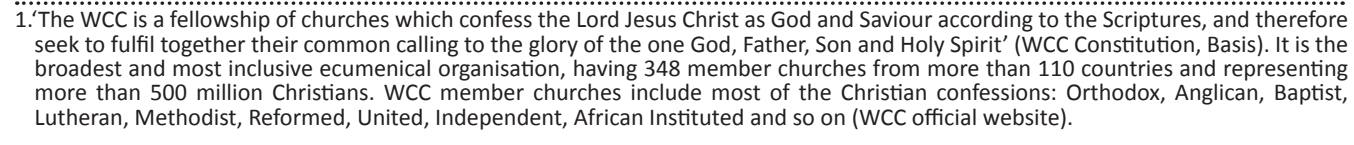
broadest and most inclusive ecumenical organisation, having 348 member churches from more than 110 countries and representing
more than 500 million Christians. WCC member churches include most of the Christian confessions: Orthodox, Anglican, Baptist, Lutheran, Methodist, Reformed, United, Independent, African Instituted and so on (WCC official website).

Note: Project financed from Lucian Blaga University of Sibiu research grants LBUS-IRG -2016-02.

Copyright: @ 2018. The Authors. Licensee: AOSIS. This work is licensed under the Creative Commons Attribution License. 
from South Africa is indeed a founding member of the WCC. I found in the WCC archives another letter dated 09 January 1947 addressed by W. Nicol, Moderator of the Synod of the Dutch Reformed Church in Transvaal, to Dr W. A. Visser ' $t$ Hooft, the first WCC General Secretary² (WCC Archives: 1977). The letter was written in Dutch and was a response to a previous letter addressed by Visser 't Hooft. It has an interesting, almost prophetic content, because it touches upon a few points that would dominate the history of the WCC's relationship with the Dutch Reformed tradition from South Africa for decades. These points can be summarised as follows:

1. Enthusiasm is expressed on the idea of creating a World Council and on possible participation of the Dutch Reformed Church family in it:

Dr Nicol writes: Personally, I would very much want the Dutch African Churches to be represented in the World Council. We have so much to learn from our fellow Christians from other countries. (WCC Archives 1947)

2. W. Nicol explained to his friend, Dr Visser 't Hooft, the reality of the Dutch Reformed family, which has several churches and synods that enjoy independency in decisionmaking but are at the same time under the umbrella of one church. He expressed his opinion that each church of the Dutch Reformed tradition in South Africa and each synod should be consulted about membership in the WCC. Dr Nicol provides Dr Visser 't Hooft with the postal addresses and names necessary for further consultation and communication.

3. The issue of apartheid was at that time already on the table. I will not say more about this matter but rather hand a copy of the letter to the present leadership of the Dutch Reformed Church. One can however imagine what it meant for some people in that time, namely 1947, the idea of creating the United Nations and other global organisations like the WCC, which talked openly about unity of the world, about equality and universal human rights.

Some tensions between the WCC and the Dutch Reformed Church were already experienced during the Second WCC General Assembly in Evanston, IL, US (15August 1954 - 31 August 1954), when the racial policy in Southern Africa was heavily criticised. Gerhard Brenneke (1954) in an article on the Evanston Assembly writes that:

... Divergences of opinion did exist between the Dutch Reformed Church of South Africa ... and most of the other delegates. This led the delegates of the Reformed Churches from South Africa to make a statement to the Assembly which was read by Dr. Brink. ${ }^{3}$ Commenting on Resolution No. 1 it stated: 'We appreciate the argument that no resolution of this Assembly has mandatory

2.Willem, Adolf Visser't Hooft (1900-1985) was the first secretary general of the WCC (1948-1966) and a leading figure of the beginnings of the ecumenical movement in the 20th century. Dutch by origin, Visser 't Hooft started his ecumenical experience with the Student Christian Movement. At the 1938 meeting in Utrecht, Holland, he was nominated by the provisional
der Bent et al. 2002:1195-1197).

3.Dr C. B. Brink was at that time the moderator of the Dutch Reformed Church of the Transvaal. power over member Churches and that certain recommendations, and especially Resolution No. 1, are intended to stimulate the independent thought and action of certain churches in specific situations. But we feel constrained to say that at this stage of ecumenical discussions in this matter, it may have the opposite effect by so prejudicing the issue at stake for some Churches that fruitful action for them will be gravely jeopardised ... However we are not offering an amendment, nor do we intend to record our votes against what is being proposed'. (p. 52)

The text of the Resolution No. 1 (1954) was unequivocal:

In the matter of the Church`s task amid racial and ethnic tensions the Second Assembly of the World Council of Churches declares its conviction that any form of segregation based on ethnic or racial tensions is contrary to the gospel and is incompatible with the Christian doctrine of man and with the nature of the Church of Christ. The Assembly urges the Churches within its membership to renounce all form of segregation and discrimination and to work for their abolition within their own life and within society. (p. 55)

The last paragraph of the Resolution No. 1 (1954) strengthened the unequivocal words:

... the ecumenical movement by its very nature has been committed to a form of fellowship in which there is no segregation or discrimination. The Assembly ... confirms this practice as the established policy of the Council. (p. 53)

The tension between the representatives of the Dutch Reformed Church family and the rest of the Assembly had been very strong in Evanston. However, Brennecke writes that they were also constructive, thanks to the contributions of Dr Brink. Brennecke concludes: 'the discussion clearly revealed the intention of the participants to adhere to the motto of the Amsterdam Assembly: "We intend to stay together"' (1954:52).

A certain level of relationship was maintained between the WCC and the Dutch Reformed Church family until 1960, when the situation had changed radically because of the Sharpeville killings (21 March 1960), when 69 unarmed African apartheid protesters were murdered by police forces. This abominable act was sharply criticised by the international community. It created also high tensions in South Africa between the Dutch Reformed Church and the English-speaking churches. The Archbishop of the Anglican Church in South Africa of that time, Joost de Blank, asked the WCC 'to expel the Dutch Reformed Church from its fellowship' (Sjollema 2009:471). Also, the creation of the Republic of South Africa (31 May 1961) when apartheid became the official ideology of the new republic seriously damaged the WCC-Dutch Reformed Church relationship.

In this extremely tense context, the WCC organised in December 1961 for its eight member churches in South Africa the famous Cottesloe Consultation, in which apartheid and racism were radically condemned. At the request of the South African government, the Dutch Reformed Church left the WCC (2009:471). In any case, the 
Dutch Reformed Church was not officially excluded from WCC fellowship, because constitutional provisions for such an exclusion procedure did not exist in that time in the WCC Constitution. They were introduced only by the Busan Assembly of 2013 (WCC Rules I, 6). I was unable to find in the WCC archives an official letter from the Dutch Reformed Church to the WCC in which the latter was informed about the resignation of this church from WCC fellowship. Most probably such a resignation letter was never sent. The Dutch Reformed Church probably preferred to turn its back on the WCC and remain indifferent to its activities. In any case, after the fourth WCC Assembly, Uppsala, Sweden (04 July 1968 - 19 July 1968), launched the Programme to Combat Racism, the Dutch Reformed Church chose to stay out of WCC fellowship.

After decades of no relationship, in the 1980s, the Dutch Reformed Church and WCC started having contact again. The result was that the Dutch Reformed Church was represented at the 7th WCC Assembly in Canberra, Australia, 07-20 July 1991, by two professors: Johan Heyns and Pieter Potgieter. They were registered as guests. It was the first presence of Dutch Reformed Church representatives at a WCC General Assembly since New Delhi, 1961.

The Dutch Reformed Church was represented at the next WCC General Assemblies:

- at the 8th Assembly, Harare, Zimbabwe, 03-14 December 1998 by Dr W.J. Botha, registered as 'observer'

- at the 9th Assembly, Porto Alegre, Brazil, 14-23 February 2006 by Dr Jacobus Johannes Gerber and Prof. Dr Piet Meiring, who were registered as observers (Rivera-Ragán 2007:415).

\section{The application of the Dutch Reformed Church for membership in the World Council of Churches}

After some preliminary discussions, on 08 August 2012, Dr Kobus Gerber, at that time General Secretary of the Dutch Reformed Church, had sent by email to WCC headquarters in Geneva an application for readmission of his church into the World Council of Churches (WCC - Church and Ecumenical Relations - Dutch Reformed Church [WCCCER-DRC], 08 August 2012). In the letter that accompanied the application for readmission, Dr Gerber motivated the application of his church as follows:

We apply because we believe that after 51 years since we left we have so transformed that we can take our seat with integrity in the family of WCC. Our re-admittance to the WCRC is proof of this. (WCC-CER-DRC, 08 August 2012)

In the same letter Dr Gerber mentioned an essential aspect:

Although our General Synod already in 2007 decided to apply for membership, we postponed the process so that we could come to a point where there is significant progress in our church unification processes with the family of the Dutch Reformed Churches. (WCC-CER-DRC, 08 August 2012)
The application was carefully analysed by WCC General Secretary Rev. Dr Olav Fykse Tveit and by the staff, and three important preliminary decisions were taken:

1. The application would be treated not as admission into the WCC, but as readmission, because the Dutch Reformed Church had been a founding member of the WCC. However, in such a case the process of readmission would be the same as for an applicant that never had been part of WCC fellowship: 'A church which has resigned but desires to re-join the World Council must again apply for membership' (WCC Rules I.6.a.).

2. Consultation on this application with other South African churches of the same Dutch Reformed tradition was needed, in order to understand whether readmission of the Dutch Reformed Church to WCC fellowship might support the process of reunification within the Dutch Reformed family in South Africa.

3. Because the Dutch Reformed Church was readmitted into the World Communion of Reformed Churches in 1998 after a long process of analysis that was finalised with signing a declaration of rejection of apartheid as 'wrong and sinful', readmission to the WCC would not include repetition of the same process but the process organised by the confessional family of the Dutch Reformed Church would be trusted.

The Permanent Committee on Consensus and Collaboration of WCC gathered from 04 to 06 March 2012 in Paralimni, Cyprus, analysed the application of the Dutch Reformed Church for readmission to the WCC and formulated a recommendation. The report (World Council of Churches Church and Ecumenical Relations - The Permanent Committee on Consensus and Collaboration [WCC-CERPCCC] report 2012) of this committee stated:

The Permanent Committee received information about an application from the Dutch Reformed Church (South Africa). It appreciated the repentance of the church for its role in apartheid was encouraged by the forgiveness and reconciliation lived out at a local level by the churches in South Africa and was supportive of the unification process underway amongst the four Reformed churches accompanied by the World Communion of Reformed Churches. (p. 3)

The Permanent Committee recommends that a visit be organised to the Dutch Reformed Church to discern more in the application process, and that the normal process for applications be maintained. Decisions on membership applications are taken by the central committee.

Based on the recommendation of the Permanent Committee, a delegation visited the Dutch Reformed Church from 29 January 2013 to 01 February 2013. The members of the delegation were as follows:

- Rev. Dr Bernice Powell Jackson, at that time WCC president from North America, United Church of Christ, and a well-known opponent of apartheid.

- Rev. Prof. Dr Simon Dossou, at that time WCC president for Africa, Protestant Methodist Church of Benin.

- Archpriest Dr Daniel Buda, Romanian Orthodox Church, Church and Ecumenical Relations of WCC, staff. 
The program of the visit included an encounter with the Faculty of Theology, University of Pretoria, a meeting with the Executive Council of the Dutch Reformed Church, meetings with some WCC member churches in South Africa and with the general secretary of the National Council of Churches in South Africa, visits to diaconal organisations, networks and groups of the Dutch Reformed Church.

The report of the team visit formulated the following conclusions and recommendations (WCC-CER-DRC-report visit-Jan-Feb. 2013): The delegation evaluated the visit (i.e. to the Dutch Reformed Church) and made the following conclusions:

- Dutch Reformed Church officially rejected 'all forms of racism', took a strong stance against apartheid and asked for forgiveness. Its readmission in WARC/WCRC was preceded by a careful process which concluded that Dutch Reformed Church broke away with the past. Apart of the official statement, WCC delegation certifies that Dutch Reformed Church shows, at different levels, a genuine repentance regarding the mistakes done in the past. However, as Dutch Reformed Church leadership recognized, there are still many things that needs to be changed [sic], especially in terms of mentality and attitude.

- Dutch Reformed Church is progressively reintegrating into the ecumenical movement. Along with the readmission in the confessional bodies and in the National Council of Churches in South Africa, Dutch Reformed Church was recently admitted in the All Africa Conference of Churches (AACC). These are clear signs that Dutch Reformed Church gained confidence in the eyes of reformed churches worldwide, as well as in the eyes of South African and African churches.

- Dutch Reformed Church is progressively using its resources for the good of South African and African Christianity. WCC delegation acknowledges their efforts to extend their platform for theological education and their social and diaconal activities to a broader constituency than Dutch Reformed Church. However, Dutch Reformed Church still needs to continue its efforts to open its constituencies to broader circles than its own Dutch environment.

Based on the analysis of the official application of Dutch Reformed Church for readmission in the WCC and on the conclusion of the visit described, after consulting the South African WCC member churches, as well as the World Alliance of Reformed Churches and AACC leadership, being fully aware that the transformations that Dutch Reformed Church needs to achieve could be realised better as part of the ecumenical family, the team visit recommends that Dutch Reformed Church is readmitted in the fellowship of WCC as a member church. The period until the next WCC Central Committee meeting should be used for monitoring Dutch Reformed Church activities in order to carefully observe its progress in growing ecumenical commitment as well as in conducting the changes for which Dutch Reformed Church committed itself. WCC governing bodies, in consultation with AACC and South African churches should seriously consider initiating a program accompaniment for the integration of Dutch Reformed Church in the ecumenical family.

The Executive Committee of the WCC gathered in Bossey, Switzerland, from 05 to 08 March 2013, analysed the report of the team visit and had extensive discussions around it. Two important aspects are to be mentioned here:

1. The fact that the Dutch Reformed Church for the first time in history applied and became member of the AACC was interpreted as a clear sign that the church wanted to be part of Christianity in Africa.

2. The voice of African representatives in the Executive Committee openly supporting readmission was crucial for the decision made.

Therefore the Executive Committee decided:

(a) to welcome the application of Dutch Reformed Church; (b) to refer the application to the central committee for a final decision; (c) to encourage the general secretary to extend an invitation to the Dutch Reformed Church to attend the assembly as 'delegated observers'. (Minutes of Executive Committee 2013:10)

Indeed, the Dutch Reformed Church was represented at the 10th WCC Assembly (30 October 2013 - 08 November 2013) of the WCC by Dr Kobus Gerber (Elinda \& Theodore 2014:410). As the WCC staff responsible for staffing this committee, I can witness that his role as an advisor to the Policy Reference Committee of the Assembly, especially in issues related to African Christianity, was highly appreciated.

As part of the monitoring proposed by the team visit, the WCC general secretary approved for me as programme executive responsible for applications for membership a visit to South Africa, from 20 to 24 March 2014. I attended an international conference on church polity at the University of Pretoria and I continued the process of consulting other South African churches. Several meetings with Dutch Reformed Church leadership contributed to a better understanding of the history and present situation of this church.

The Central Committee of the WCC, which gathered in Geneva, 02-08 July 2014, was supposed to make a first decision regarding the application of the Dutch Reformed Church for readmission. According to the WCC Rules (I.6.) for accepting new members, the Central Committee is mandated to review an application for membership and to decide whether a church 'shall be accepted for an interim period of participation in the work of the world Council of Churches'. The ordinary procedure for taking such a decision does not imply necessarily the presence of a representative of the applicant church while debating its application for membership. However, WCC leadership decided to invite Dr Gerber to be present also in this Central Committee and respond to questions from Central Committee members. 
As usual in Central Committee meetings, the issue of membership matters had been referred to the Policy Reference Committee of the Central Committee. I presented a report (WCC-CC-2014-PRC-membership matters) in which the following points were highlighted:

- Dutch Reformed Church representation in the WCC General Assembly and the important contribution of Dr Gerber

- the fact that in the 10th General Assembly of the AACC, which took place in Kampala, Uganda, in 2013:

a female delegate of the Dutch Reformed Church was elected as member of the central committee of All Africa Conference of Churches, which shows that the ecumenical activity of the Dutch Reformed Church in Africa is widely recognized by the fellowship of AACC. (WCC-CC-2014-PRC-membership matters)

- positive conclusions of my visit to South Africa in March 2014

- positive reactions of the National Council of Churches in South Africa (which had a change in leadership after the team visit in 2013) and of South African churches.

An impressive moment constituted the direct encounter of the Policy Reference Committee of the Central Committee with Dr Gerber. After Dr Gerber responded to several questions and left the floor so that the committee could formulate a decision, two US bishops who were members of the committee, one male and one female, one Orthodox and one Methodist, highlighted the fact that all those present in that room were part of a historical decision: a founding member of WCC was coming back home. With no voice against or even in abstention the Policy Reference Committee formulated the following decision, which was accepted by the plenary of the Central Committee of WCC:

to accept the re-admission of the Dutch Reformed Church into WCC fellowship; to establish an interim period of two years for Dutch Reformed Church. A final decision was supposed to be taken by the Central Committee in 2016. (WCC-CC-2014-PRCmembership matters- final decisions)

During the interim period, the Dutch Reformed Church was invited to attend several WCC meetings and consultations. A change in leadership of the Dutch Reformed Church took place, according to the Dutch Reformed Church rules and regulations, but the commitment to be readmitted to WCC fellowship remained the same. According to the WCC regulations, the general secretary consulted all WCC member churches, especially those in South Africa, on the issue of readmission of the Dutch Reformed Church to WCC fellowship. The file on the readmission of the Dutch Reformed Church (WCC-CER-DRC-church responses) to WCC fellowship contains written responses (emails or ordinary letter) from the following South African churches: Methodist Church of Southern Africa (02 July 2014), Uniting Reformed Church in Southern Africa (23 June 2014), Evangelical Lutheran Church in Southern Africa (05 June 2014), United Congregational Church in Southern Africa (29 May 2014). All these churches agreed that the Dutch Reformed Church should be readmitted to WCC fellowship; however, the way they expressed this agreement varied from enthusiasm and full support to not opposing readmission.

Therefore, in the Central Committee that took place in Trondheim from 22 to 28 June 2016, the Dutch Reformed Church was represented by Dr Gustav Claassen, General Secretary, and by Rev. Nelis Janse van Rensburg, Moderator. In response to the decision to readmit the Dutch Reformed Church as a full member of the WCC, Rev. Janse van Rensburg responded with an impressive message. In particular, the word of thanks to the WCC for not closing the doors to the Dutch Reformed Church was very moving. The atmosphere created in the plenary of the WCC cannot be expressed in words: I saw tears in the eyes of several Central Committee members. For me, as WCC staff dealing with membership matters it was a high point to see a church readmitted to the WCC, together with other two other applicant churches, one from Africa and the other one from Asia.

I would like to mention here the words of Dr Agnes Aboum, WCC Central Committee Moderator, expressed after this historical event:

We are delighted to welcome these churches to the ecumenical fellowship. And it is a special joy to welcome back to the fellowship the Dutch Reformed Church, one of our founding member churches and now, a generation after the end of apartheid, a partner in building a future of justice for all peoples. ${ }^{4}$

I would like to refer also to the way the Dutch Reformed Church was integrated into WCC fellowship. I would like to mention here only two aspects, which are real evidence that the Dutch Reformed Church is actively engaged in WCC fellowship:

1. The leadership of the Dutch Reformed Church, in cooperation with the Theological Faculty of Pretoria University, invited and generously financed the Commission on Faith and Order of the WCC to meet in Pretoria, 15-21 June 2017. The Faith and Order Commission meeting was included in the series of academic events and festivities that marked the centenary of the Faculty of Theology in Pretoria, which serves the Dutch Reformed Church and other churches. ${ }^{5}$

2. The Dutch Reformed Church, together with the Uniting Reformed Church in Southern Africa, applied to organise the next WCC Assembly in Cape Town (South Africa). This is a real sign of taking very seriously WCC membership. It was the first time in WCC history that a church applied to host a WCC assembly less than 2 years after becoming a member. One can only salute and congratulate such initiative! The WCC Central Committee gathered in June 2018 in Geneva and decided that the venue of the next Assembly would be Karlsruhe, Germany; however, everyone present at that meeting, that is, Central Committee members, observers and WCC

4.https://www.oikoumene.org/en/press-centre/news/new-member-churcheswelcomed-in-wcc

5.For more details, see the series of articles and texts published in HTS 73 (1), 2017. 
staff, valued the ecumenical commitment of the Dutch Reformed Church family expressed in their desire to host a WCC Assembly.

\section{Some concluding remarks}

I would like to conclude the story and analysis of the journey of the Dutch Reformed Church back into WCC fellowship with the following remarks:

1. The process of the readmission of the Dutch Reformed Church into WCC fellowship was a complex one. It postulated a careful reading of WCC rules regarding readmission and a complex process of consultation with WCC member churches and ecumenical partners in South Africa and in Africa. The attitude and actions of the WCC leadership and staff were dominated by carefulness. One needed to make sure that the Dutch Reformed Church was liberated from the apartheid ideology. Therefore more visits to the church and more encounters with its leadership and constituencies took place.

2. The process was characterised by accountability. The repentance done by the Dutch Reformed Church when it was readmitted to the confessional family was recognised by the WCC and therefore no repetition of the process was required. The same accountability was applied in relationship with other churches, with the national council on South Africa and with the AACC, as a regional ecumenical organisation of the continent. Their support for readmission played a decisive role.

3. The process once concluded caused a lot of joy, both in WCC fellowships, as well as in the Dutch Reformed Church. One must be aware that there were exceptions on both sides.

4. Therefore realism is present, as a correct attitude for guaranteed success. We all have to continue our struggle for overcoming all forms of separation and discrimination. We can be successful only if we stay together.

\section{Acknowledgements Competing interests}

The author declares that he has no financial or personal relationships which may have inappropriately influenced him in writing this article.

\section{References}

Brenneke, G., 1954, 'Inter-Group Relations - The Church Amid racial and ethnical tensions', Ecumenical Review 7(1), 49-55. https://doi.org/10.1111/j.1758-6623. 1954.tb01724.x

Elinda, N.S. \& Theodore, A.G. Jr (eds.), 2014, Encountering the God of Life, Report of the 10th Assembly of the World Council of Churches, Geneva.

Rivera-Ragán, L.N. (ed.), 2007, God, in your grace ... Official Report of the Ninth Assembly of the World Council of Churches, WCC Publications, Geneva.

Minutes of the meeting of the Executive Committee of WCC, 5-8 March 2013, 2013, Ecumenical Institute, Bossey, Switzerland, Geneva.

Sjollema, B., 2009, 'Combating Rasism: A chapter in Ecumenical History', Ecumenical Review 56(4), 470-478. https://doi.org/10.1111/j.1758-6623.2004.tb00534.x

Van der Bent, A., Hooft, V. \& Adolf, W., 2002, Dictionary of the ecumenical movement, N. Lossky et al. (eds.), 2nd edn., Geneva, pp. 1195-1197.

WCC Archives: 1937 = WCC Archives in Geneva, Switzerland, Fond Africa, 1937: Letter, dated September 29, 1936, addressed to the Dutch Reformed Church of Cape and Stellenbosch to attend the World Conference on 'Church, Community and State,' 12-25 July 1937.

WCC Archives: $1947=$ WCC Archives in Geneva, Switzerland, Fond Africa, 1947: Letter dated 9 January 1947 addressed by W. Nicol; Moderator of the Synod of the Dutch Reformed Church in Pretoria, to Dr W. A. Visser`t Hooft, the first WCC General Secretary.

WCC - CER - DRC - 8th August 2012 = WCC active file, Church and Ecumenical Relations, application of Dutch Reformed Church for re-admission; 8th August 2012: Email of Dr Kobus Gerber to Daniel Buda; with attachment.

WCC-CER-PCCC report 2012 = WCC active file, Church and Ecumenical Relations, Permanent Committee on Consensus and Collaboration; report of the meeting in Paralimni, 4-6 March 2012

WCC-CER-DRC-report visit-Jan-Feb. 2013 = WCC active file; Church and Ecumenical Relations, application of Dutch Reformed Church for re-admission; Visit report: 29 January to 1st February 2013.

WCC-CC-2014-PRC-membership matters = WCC active file; Central Committee 2014; Policy Reference Committee, Report on membership matters.

WCC-CER-DRC-church responses = WCC active file; Church and Ecumenical Relations; Dutch Reformed Church; church responses.

WCC official website: https://www.oikoumene.org/en

WCC Constitution and Rules: https://www.oikoumene.org/en/resources/documents/ assembly/2013-busan/adopted-documents-statements/wcc-constitution-and-rules 